\title{
Effectiveness of abduction orthosis for the treatment of acetabular dysplasia
}

\author{
Asetabular displazi tedavisinde abdüksiyon ortezinin etkililiği
}

\author{
Güney Yılmaz, MD(D, Sancar Bakırcıoğlu, MD®D, Rıza Mert Çetik, MD® \\ Department of Orthopedics and Traumatology, Hacettepe University Faculty of Medicine, Ankara, Turkey
}

\begin{abstract}
Objectives: This study aims to evaluate the effectiveness of full-time bracing in residual acetabular dysplasia (RAD) and the effect of previous Pavlik harness usage on the results of treatment with abduction orthosis.
\end{abstract}

Patients and methods: We retrospectively reviewed 80 patients (9 males, 71 females; mean age $6 \pm 0.8$ months; range, 5 to 7 months) with developmental dysplasia of the hip (119 dysplastic hips) treated with hip abduction orthosis. Patients with an acetabular index (AI) measurement of $30^{\circ}$ and over who used full-time hip abduction brace for six months were included in the study. Acetabular index values were measured at the initiation, third, and sixth months of treatment and the effectiveness of abduction orthosis was evaluated. The patients were analyzed for the effect of prior Pavlik harness application on abduction orthosis treatment.

Results: Mean AI value of the dysplastic hips $(n=119)$ was $33.4^{\circ} \pm 2.6^{\circ}$, which decreased to $28.5^{\circ} \pm 2.6^{\circ}$ after treatment $(\mathrm{p}<0.001)$. The AI improvement in the first three-month period was significantly faster than the second three-month period $\left(2.9^{\circ} \pm 1.9^{\circ}\right.$ vs. $\left.1.9^{\circ} \pm 1^{\circ} ; \mathrm{p}=0.013\right)$. No difference was observed in AI development between patients with or without prior Pavlik treatment $(p=0.1)$. In patients with unilateral dysplasia, dysplastic hips improved significantly faster than normal hips $(\mathrm{p}<0.001)$. As a result of a mean follow-up duration of $20.2 \pm 9.8$ months from the onset of brace treatment, 32 (32\%) hips were grouped as normal, $49(48 \%)$ as mildly dysplastic, and $22(20 \%)$ as severely dysplastic based on Tönnis criteria.

Conclusion: Hip abduction orthosis may be used in patients with RAD between 6 to 12 months of age. Acetabular index improvement was faster in the first three months of brace treatment. Dysplastic hips improved faster than normal hips, and prior Pavlik harness treatment did not alter the effectiveness of orthosis.

Keywords: Abduction brace, acetabular index, hip dysplasia, Pavlik harness.
$\ddot{O} Z$

Amaç: Bu çalışmada rezidüel asetabular displazi (RAD)'de tam zamanlı orteze almanın etkililiği ve önceki Pavlik bandajı kullanımının abdüksiyon ortezi ile tedavi sonuçları üzerindeki etkisi değerlendirildi.

Hastalar ve yöntemler: Gelişimsel kalça displazisi (119 displastik kalça) olup kalça abdüksiyon ortezi ile tedavi edilen 80 hasta ( 9 erkek, 71 kız; ort. yaş $6 \pm 0.8$ ay; dağılım, 5-7 ay) retrospektif olarak değerlendirildi. Asetabular indeks (Aİ) ölçümü $30^{\circ}$ ve üstünde olan ve altı ay tam zamanlı kalça abdüksiyon ortezi kullanan hastalar çalışmaya dahil edildi. Asetabular indeks değerleri tedavinin başlangıcında, üçüncü ve altıncı ayında ölçüldü ve abdüksiyon ortezinin etkililiği değerlendirildi. Hastalar, geçmiş Pavlik bandajı uygulamasının abdüksiyon ortezi tedavisi üzerindeki etkisi açısından analiz edildi.

Bulgular: Displastik kalçaların $(\mathrm{n}=119)$ ortalama Aİ değeri $33.4^{\circ} \pm 2.6^{\circ}$ olup tedaviden sonra $28.5^{\circ} \pm 2.6^{\circ}$ ye düştü $(\mathrm{p}<0.001)$. İlk üç aylık dönemdeki Aİ iyileşmesi ikinci üç aylık dönemden anlamlı olarak daha hızlıyd $1\left(2.9^{\circ} \pm 1.9^{\circ}\right.$ ye karşı $\left.1.9^{\circ} \pm 1^{\circ} ; \mathrm{p}=0.013\right)$. Geçmiş Pavlik tedavisi olan ve olmayan hastalar arasında Aİ gelişiminde farklılık gözlenmedi $(\mathrm{p}=0.1)$. Tek taraflı displazisi olan hastalarda, displastik kalçalar normal kalçalardan anlamlı olarak daha hızlı iyileşti $(\mathrm{p}<0.001)$. Tönnis ölçütleri temel alındığında, ortez tedavisinin başlangıcı itibariyle ortalama $20.2 \pm 9.8$ aylık takip süresi sonucunda, 32 (32\%) kalça normal, 49 (48\%) kalça hafif displastik ve 22 (20\%) kalça şiddetli displastik olarak grupland.

Sonuç: Altı-oniki ay yaş aralığındaki RAD’li hastalarda kalça abdüksiyon ortezi kullanılabilir. Asetabular indeks iyileşmesi ortez tedavisinin ilk üç ayında daha hızlıydı. Displastik kalçalar normal kalçalardan daha hızlı iyileşti ve geçmiş Pavlik bandajı tedavisi ortezin etkililiğini değiştirmedi.

Anahtar sözcükler: Abdüksiyon ortezi, asetabular indeks, kalça displazisi, Pavlik bandajı.

Received: November 26, 2018 Accepted: January 20, 2019

Correspondence: Güney Yılmaz, MD. Hacettepe Üniversitesi Tıp Fakültesi Ortopedi ve Travmatoloji Anabilim Dalı, 06100 Sıhhiye Ankara, Turkey. Tel: +90 533 - 7192617 e-mail: güney.yilmaz@hacettepe.edu.tr 
Developmental dysplasia of the hip (DDH) is a common orthopedic disorder of unknown etiology. Left untreated, DDH may cause significant morbidity in the affected hip. ${ }^{[1]}$

The initial treatment choice for the management of DDH under six months of age is the Pavlik harness, which has proven to be both safe and effective in the literature. ${ }^{[2-4]}$ Success rates of the harness is high, reaching over $90 \%$ in some studies. ${ }^{[5]}$ Although the success rate of Pavlik harness treatment in dislocated hips is high, residual acetabular dysplasia (RAD) is a well-known entity after treatment. Patients may present with RAD after proper harness treatment or the diagnosis can be established during the initial orthopedic evaluation of patients older than six months with no previous treatment.

Spontaneous resolution of RAD is unlikely, ${ }^{[6]}$ and the ideal method of treatment is controversial after six months of age. Since the treatment of patients with Pavlik harness is cumbersome over six months of age, abduction orthoses are widely used for this patient population. However, there is insufficient evidence in the literature supporting the use of these devices, particularly for children with dysplastic but stable hips. ${ }^{[7,8]}$ Gans et al. ${ }^{[9]}$ have compared part-time bracing against observation alone, and reported better results with part-time bracing. In this study, we aimed to evaluate the effectiveness of full-time bracing in RAD and the effect of previous Pavlik harness usage on the results of treatment with abduction orthosis. ${ }^{[10]}$

\section{PATIENTS AND METHODS}

We retrospectively reviewed a total of 93 patients treated for DDH between February 2015 and June 2017 at Hacettepe University Faculty of Medicine Department of Orthopaedics and Traumatology. Thirteen patients were excluded from the study; seven were lost to follow-up, five were noncompliant with the orthosis, and one required open reduction and spica casting due to a dislocated hip detected at the fourth month of bracing. The remaining 80 patients (9 males, 71 females; mean age $6 \pm 0.8$ months; range, 5 to 7 months) were included in the study. Patients' acetabular index (AI) was $\geq 30^{\circ}$ as defined by Tönnis, ${ }^{[1]]}$ which represents two standard deviations over the mean. All patients had stable hip joints. Ortolani test and Barlow maneuvers were negative in all patients. We recorded patients' demographic information, family history, presentation at delivery (vertex vs. breech), and prior treatment with Pavlik harness. Patients with syndromic or teratologic hip dysplasia and those who underwent open/closed reduction were excluded. The study protocol was approved by the Hacettepe University Faculty of Medicine Ethics Committee. A written informed consent was obtained from parents of each patient. The study was conducted in accordance with the principles of the Declaration of Helsinki.
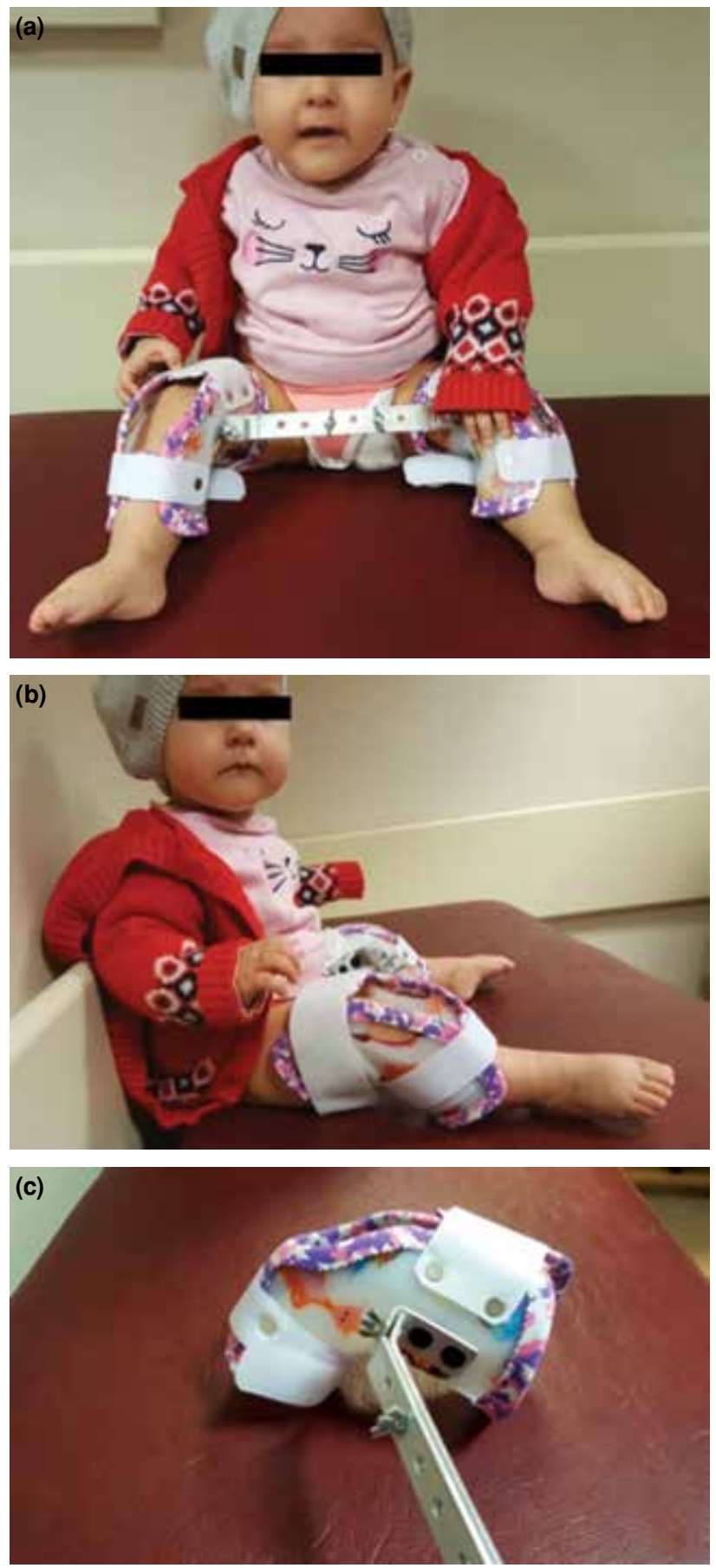

Figure 1. Abduction brace used allows knee flexion and hip flexion/extension while keeping hips in $45^{\circ}$ to $50^{\circ}$ of abduction. (a, b) Eight-month-old girl in hip abduction brace. (c) Side view of brace showing that knee is flexed. 
Abduction brace (Figure 1a-c) was applied in all patients for six months full-time (only one hour of brace-free time was allowed for bathing etc.). The brace maintains at least $40^{\circ}$ to $50^{\circ}$ of hip abduction, $30^{\circ}$ to $45^{\circ}$ of knee flexion while allowing hip flexion and extension. Acetabular Index values were measured during the first clinical visit, and during the third and sixth months of brace treatment. The radiographic parameters were measured on standard supine anteroposterior pelvis X-rays and the AI was recorded (Figure 2). ${ }^{[12]}$ The measurement of the AI has shown good intra- and interobserver reliability in previous studies. ${ }^{[13]}$ In our study, the AI was measured by a single researcher and an intraclass correlation coefficient (ICC) analysis was also performed.

Acetabular index values in the dysplastic and normal sides were evaluated and compared at the initial and follow-up visits. Changes in the AI values during the first and second three-month intervals were evaluated. Patients with or without previous Pavlik harness treatment were compared with respect to AI correction.

Patients' most recent pelvic radiographs were also evaluated and the AI values were determined. The data presented by Tönnis. ${ }^{[1]}$ including normal AI values in pediatric population were used to classify
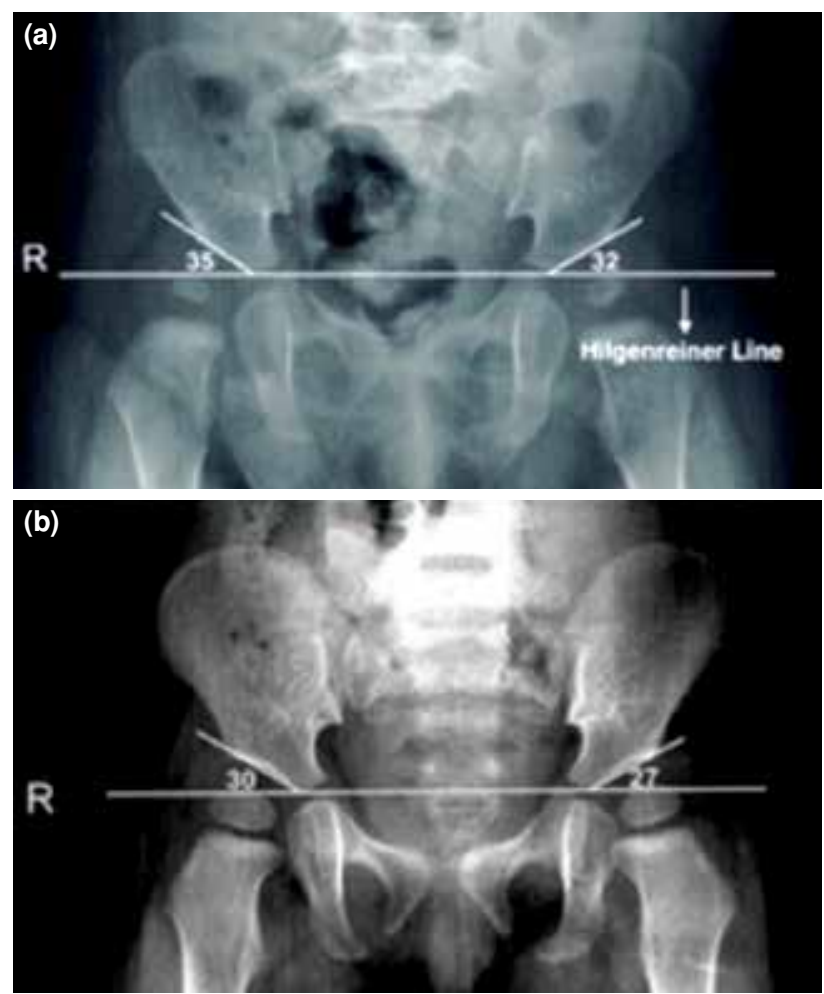

Figure 2. Acetabular index measurement: Initially (a) and at sixth-month follow-up. (b) X-ray after brace treatment. patients' hip morphology as normal, mildly dysplastic, and severely dysplastic during the last follow-up visit.

\section{Statistical analysis}

Statistical analyses were performed using the IBM SPSS version 22.0 software (IBM Corp., Armonk, NY, USA). Descriptive statistics were presented with means and standard deviations since the variables were distributed normally. The paired samples t-test, independent samples t-test, and repeated measures analysis of variance were used for comparing the means. Intra- and interrater reliability were evaluated by ICC. A $p$ value of less than 0.05 was considered as statistically significant.

\section{RESULTS}

Of the 80 patients, $41(51.2 \%)$ had unilateral dysplasia while $39(48.8 \%)$ had bilateral dysplasia. Residual acetabular dysplasia was detected in 119 hips (74.4\%) and 41 hips (25.6\%) were normal. Twenty seven patients presented breech at delivery, and 15 patients had a family history of DDH.

The mean AI was $33.4^{\circ} \pm 2.6^{\circ}$ at the onset of the brace treatment of 119 dysplastic hips (right hip [ $n=50] 33.5^{\circ} \pm 2.9^{\circ} /$ left hip [ $\left.\left.\mathrm{n}=69\right] 33.3^{\circ} \pm 2.3^{\circ}\right)$ and this value decreased to $28.5^{\circ} \pm 2^{\circ}$ (right hip $28.7^{\circ} \pm 2.2^{\circ}$ / left hip $28.4^{\circ} \pm 1.9^{\circ}$ ) after six months of full-time abduction brace treatment $(p<0.001)$. There was no statistically significant difference between right and left hips in terms of AI change in six months treatment period $(\mathrm{p}=0.949)$. The 41 non-dysplastic hips were measured to have a mean $\mathrm{AI}$ of $26.9^{\circ} \pm 1.8^{\circ}$; this value decreased to $23.1^{\circ} \pm 2.2^{\circ}$ after six months of treatment $(\mathrm{p}<0.001)$ (Figure 3).

The progression of AI values in dysplastic hips were also analyzed by dividing the abduction orthosis

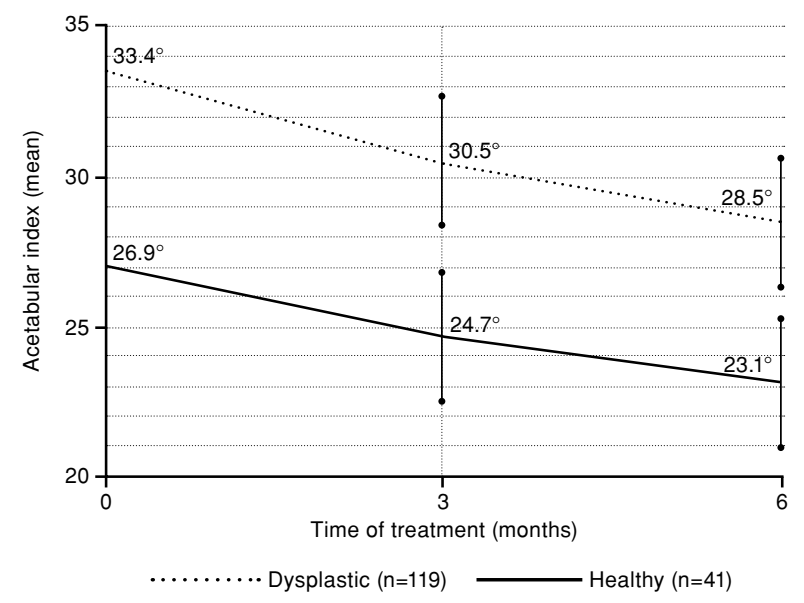

Figure 3. Improvement of acetabular index in six months: Normal and dysplastic hips. 
treatment into two time periods as zero-three months and three-six months. When the 119 dysplastic hips were analyzed, the mean decrease of $\mathrm{AI}$ was $2.9^{\circ} \pm 1.9^{\circ}$ in the first three months and $1.9^{\circ} \pm 1^{\circ}$ in the second three months of treatment. The difference of means was statistically significant $(\mathrm{p}<0.013)$ (Figure 4$)$.

Fifty-one of the 80 patients (76 hips) had prior Pavlik harness treatment while the remaining 29 patients (43 hips) did not. When two groups were analyzed, there was a statistically significant difference in initial AI values at the beginning of the treatment $(\mathrm{p}=0.04)\left(33.1^{\circ} \pm 2.3^{\circ}\right.$ in previous Pavlik treatment group; $34.1^{\circ} \pm 2.9^{\circ}$ in no previous Pavlik treatment group). After six months of treatment with an abduction orthosis, the mean decrease in AI for the Pavlik group was $4.7^{\circ} \pm 1.5^{\circ}$, while it was $5.2^{\circ} \pm 1.9^{\circ}$ in patients with no previous Pavlik treatment. There was no difference between the two groups in terms of change in AI ( $\mathrm{p}=0.1$ ) (Figure 5).

Acetabular development in 41 patients with unilateral dysplasia was also analyzed in terms of any difference between normal and dysplastic hips. The mean initial AI value of the dysplastic hips of 41 patients was $33.6^{\circ} \pm 2.3^{\circ}$, which decreased to $28.1^{\circ} \pm 2^{\circ}$; the mean initial AI value of the healthy hips was $26.9^{\circ} \pm 1.8^{\circ}$, while it decreased to $23.1^{\circ} \pm 2.2^{\circ}$ at the end of the six-month brace treatment. The rate of AI correction was significantly faster in the dysplastic hips compared to the healthy hips (mean AI correction is $5.5^{\circ} \pm 1.9^{\circ}$ for the dysplastic hips and $3.8^{\circ} \pm 1.5^{\circ}$ for the normal hips; $\mathrm{p}<0.001$ ) (Figure 6).

Patients were examined periodically after the brace treatment was over. The AI values of the dysplastic hips in the last visit were stratified into normal, mild dysplasia, and severe dysplasia based

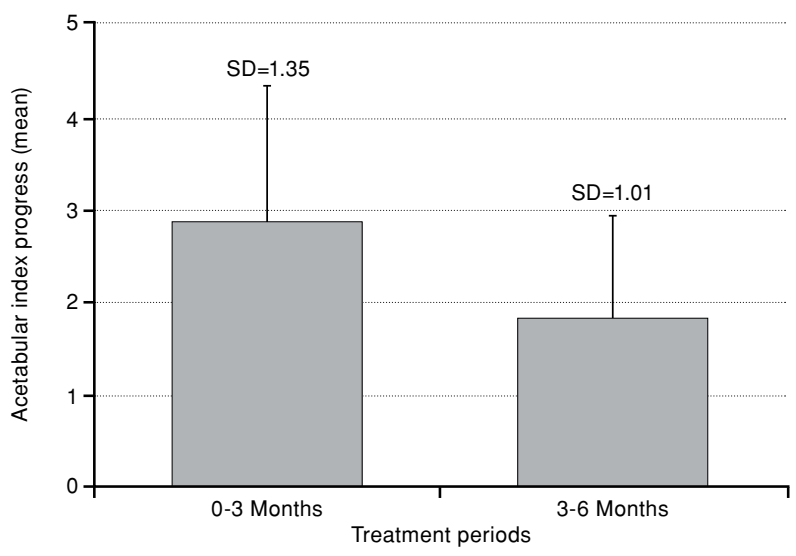

Figure 4. Acetabular index change in dysplastic hips in first and second three months of treatment.

SD: Standard deviation. on the normal AI values of the pediatric population presented by Tönnis. ${ }^{[1]}$ With the mean follow-up of $20.2 \pm 9.8$ months from the onset of brace treatment, 103 of the 119 dysplastic hips were stratified into one of three groups: $32(32 \%)$ hips were grouped as normal, $49(48 \%)$ as mildly dysplastic, and $22(20 \%)$ as severely dysplastic.

According to the model previously described, an ICC analysis was carried out that showed good reliability. The calculated ICC of the initial, third, and sixth month radiographs were as follows: $0.98,0.96$, and 0.99 .

\section{DISCUSSION}

Although the ultrasound screening programs have decreased the number of patients requiring late open/closed reductions for $\mathrm{DDH}_{,},[14,15]$ there is still a need for the treatment of RAD.

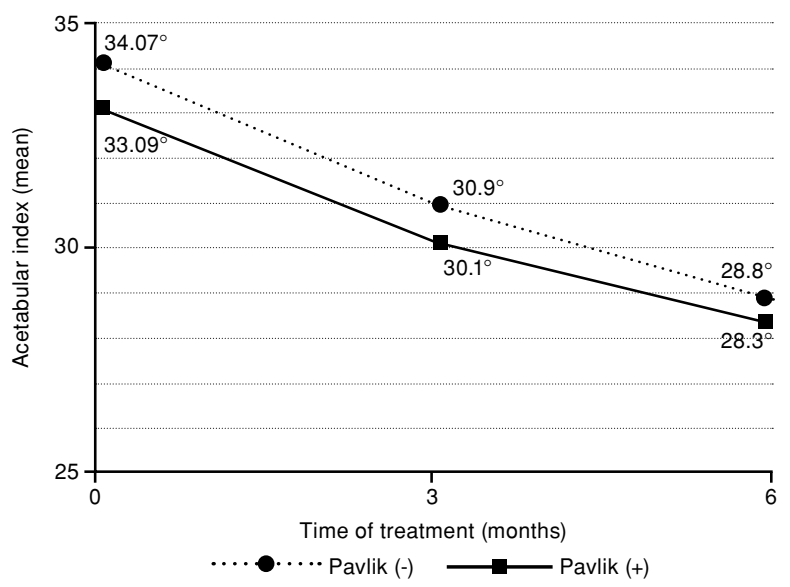

Figure 5. Improvement of acetabular index in six months: patients with versus without prior Pavlik treatment.

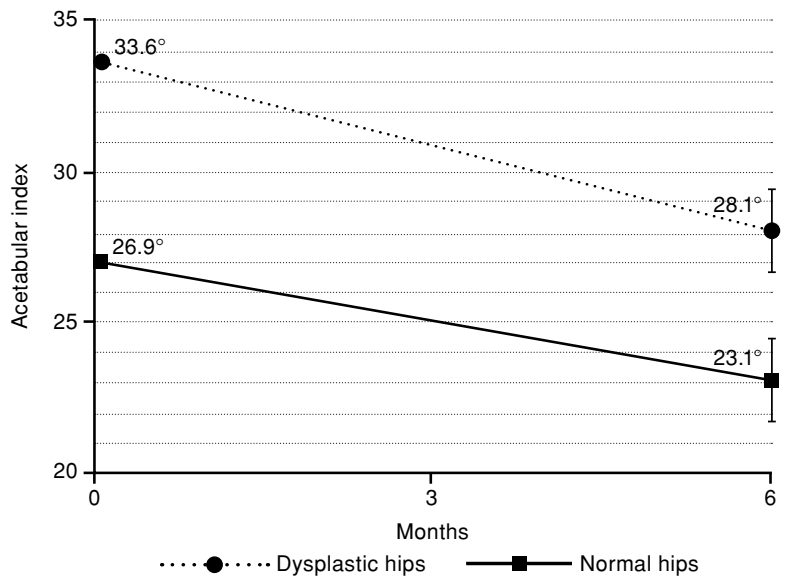

Figure 6. Acetabular index values in unilateral hip dysplasia before and after treatment. Normal hips versus dysplastic hips. 
Ultrasonographic evaluation does not always correlate with AI measurements after six months, and even ultrasonographically-proven successful Pavlik harness treatment can result in RAD in some patients at follow-up. ${ }^{[16]}$ Treatment of RAD between six months and one year of age is controversial.

Abduction orthosis is the treatment of choice in RAD when the patient is older than six months. ${ }^{[7-9]}$ In a retrospective study of 76 hips with RAD by Gans et al., ${ }^{[0]}$ part-time abduction bracing was found to be superior against observation alone in patients with stable but dysplastic hips, similar to our study group. We did not have a control group where the brace was not used since we use full-time abduction bracing on a routine basis for RAD. In another report by Sankar et al., ${ }^{[8]}$ abduction brace (Fillauer, Chattanooga, Tennessee, USA) was used in patients with previous failed Pavlik harness treatment. The results were compared with a historical group of patients who had closed reduction and casting for the same indication. One year after the treatment, acetabular indices were similar between both groups indicating the satisfactory results obtained with a brace. Besides, the avascular necrosis rate was statistically lower in the brace group than the closed reduction group. On the other hand, brace treatment in seven patients with a dislocated or dislocatable hip failed in a study by Ibrahim et al. ${ }^{[17]}$ As opposed to this report, we have not used abduction brace in the treatment of patients who had dislocation or subluxation of the hip joint. All patients with RAD in our study group had stable hips except one who had tracheomalacia with an undiagnosed collagen disorder. He had dislocation of the left hip in the brace and eventually underwent open reduction.

Our study showed that brace treatment is safe and effective in a group of 80 patients (119 hips). We revealed that the treatment is more effective in the first three-month period and the improvement in AI decreases afterwards (Figure 4), which may be an important factor to consider in follow-up. If a patient fails to show significant improvement in the first three months, the surgeon might expect an even slower improvement in the second three months.

Prior treatment with a Pavlik harness is a frequently encountered situation in patients with RAD. We have failed to find any study in the literature regarding the effect of Pavlik harness treatment on subsequent abduction bracing for RAD. In our study, AI measurements in patients with previous Pavlik harness treatment at the beginning of abduction brace treatment were significantly lower than patients with no Pavlik treatment before. AI measurements in dysplastic hips of two groups have become statistically indifferent by the end of the treatment. Although patients with no previous Pavlik harness treatment had more improvement in AI measurement, the statistical analysis showed that prior Pavlik harness treatment had no effect on abduction brace treatment.

Tönnis $^{[1]]}$ reported the normal AI measurement of pediatric patients stratified by age and gender and the long-term follow-up evaluation of our patient group draws attention to another aspect of brace treatment. Although bracing effectively improved dysplastic hips in terms of AI measurements, in the latest follow-up from the onset of brace treatment (20.2 \pm 9.8 months), 32 (32\%) hips were grouped as normal, $49(48 \%)$ as mildly dysplastic, and $22(20 \%)$ as severely dysplastic when compared to previous age-matched Tönnis normal data. We consider those results as short-term and believe that longer follow-up needs to be accomplished for more accurate and reliable results.

One of the main drawbacks of our study is the lack of a control group with no treatment. Although we have observed improvement in AI in dysplastic hips, it is not possible to conclude that the results are better than the natural history. Since we recommend and apply abduction brace in every patient who had stable hips with acetabular dysplasia between six and 12 months of age, it is not possible for us to create a control group. The next drawback would be the short follow-up duration after the end of the brace treatment. Since the development of acetabular morphology is an ongoing process, patients need to be followed-up for a longer time before final decision is established for a pelvic osteotomy. We did not know the severity of hip dysplasia of patients who previously had Pavlik treatment since most of those patients were treated elsewhere. However, we included those patients in the study since they all had RAD with stable and reduced joints. Although these two groups of patients had different AI measurements at the beginning of brace treatment, the measurements were close to each other and comparable.

In conclusion, our study showed that full-time abduction bracing can be used in the treatment of RAD after six months. This study does not conclude that brace treatment is better than the natural history since a control group is lacking. Although AI corrects to normal in one-third of the patients, there will still be patients with mild or severe acetabular dysplasia according to Tönnis criteria that need to be followed-up for a longer time for acetabular remodelling. Our study showed that $20 \%$ of patients in the latest follow-up still had severe acetabular 
dysplasia according to Tönnis criteria. This group of patients needs to be followed-up closely for an early pelvic osteotomy. Majority of improvement in AI occurs in the first three months of abduction brace treatment. Moreover, previous Pavlik harness treatment does not adversely affect $\mathrm{AI}$ improvement in short-term. Studies with longer follow-up and a control group are needed to conclude if brace treatment is superior than the natural history in RAD after six months of age.

\section{Declaration of conflicting interests}

The authors declared no conflicts of interest with respect to the authorship and/or publication of this article.

\section{Funding}

The authors received no financial support for the research and/or authorship of this article.

\section{REFERENCES}

1. Thomas SR. A review of long-term outcomes for late presenting developmental hip dysplasia. Bone Joint J 2015;97:729-33.

2. Nakamura J, Kamegaya M, Saisu T, Someya M, Koizumi W, Moriya H. Treatment for developmental dysplasia of the hip using the Pavlik harness: long-term results. J Bone Joint Surg [Br] 2007;89:230-5.

3. Cashman JP, Round J, Taylor G, Clarke NM. The natural history of developmental dysplasia of the hip after early supervised treatment in the Pavlik harness. A prospective, longitudinal follow-up. J Bone Joint Surg Br 2002;84:418-25.

4. Mulpuri K, Song KM, Goldberg MJ, Sevarino K. Detection and Nonoperative Management of Pediatric Developmental Dysplasia of the Hip in Infants up to Six Months of Age. J Am Acad Orthop Surg 2015;23:202-5.

5. Grill F, Bensahel H, Canadell J, Dungl P, Matasovic T, Vizkelety T. The Pavlik harness in the treatment of congenital dislocating hip: report on a multicenter study of the European Paediatric Orthopaedic Society. J Pediatr Orthop 1988;8:1-8.

6. Vitale MG, Skaggs DL. Developmental dysplasia of the hip from six months to four years of age. J Am Acad Orthop Surg 2001;9:401-11.

7. Hedequist D, Kasser J, Emans J. Use of an abduction brace for developmental dysplasia of the hip after failure of Pavlik harness use. J Pediatr Orthop 2003;23:175-7.

8. Sankar WN, Nduaguba A, Flynn JM. Ilfeld abduction orthosis is an effective second-line treatment after failure of Pavlik harness for infants with developmental dysplasia of the hip. J Bone Joint Surg [Am] 2015;97:292-7.

9. Gans I, Flynn JM, Sankar WN. Abduction bracing for residual acetabular dysplasia in infantile DDH. J Pediatr Orthop 2013;33:714-8.

10. Atik OŞ. Which articles do we prefer to publish? Eklem Hastalik Cerrahisi 2018;29:1.

11. Tönnis D. Normal values of the hip joint for the evaluation of X-rays in children and adults. Clin Orthop Relat Res 1976;119:39-47.

12. Broughton NS, Brougham DI, Cole WG, Menelaus MB. Reliability of radiological measurements in the assessment of the child's hip. J Bone Joint Surg [Br] 1989;71:6-8.

13. Tan L, Aktas S, Copuroglu C, Ozcan M, Ture M. Reliability of radiological parameters measured on anteroposterior pelvis radiographs of patients with developmental dysplasia of the hip. Acta Orthop Belg 2001;67:374-9.

14. Wirth T, Stratmann L, Hinrichs F. Evolution of late presenting developmental dysplasia of the hip and associated surgical procedures after 14 years of neonatal ultrasound screening. J Bone Joint Surg [Br] 2004;86:585-9.

15. von Kries R, Ihme N, Oberle D, Lorani A, Stark R, Altenhofen $\mathrm{L}$, et al. Effect of ultrasound screening on the rate of first operative procedures for developmental hip dysplasia in Germany. Lancet 2003;362:1883-7.

16. Sibiński M, Adamczyk E, Higgs ZC, Synder M. Hip joint development in children with type IIb developmental dysplasia. Int Orthop 2012;36:1243-6.

17. Ibrahim DA, Skaggs DL, Choi PD. Abduction bracing after Pavlik harness failure: an effective alternative to closed reduction and spica casting? J Pediatr Orthop 2013;33:536-9. 